\title{
MANAGEMENT CONSULTING TRENDS IN SLOVAKIA IN THE LIGHT OF GLOBAL AND REGIONAL TENDENCIES
}

\author{
Zsuzsa Szeiner \\ J. Selye University Komárno, Slovakia \\ Ladislav Mura \\ J. Selye University Komárno, Slovakia \\ Zsolt Horbulák \\ University of Economics in Bratislava, Slovakia \\ Mike Roberson \\ Eastern Kentucky University, USA \\ József Poór \\ J. Selye University Komárno, Slovakia
}

\begin{abstract}
Management consulting, as we know it today, has existed for over 100 years. We review the basic concepts of consulting, outline the major steps in the development of business-related consulting, and highlight that consulting plays an important role in shaping the globalization of multinational firms. Next, we depict the specific evolutionary steps of consulting in Czechoslovakia and independent Slovakia in the light of global and regional trends. The development of Slovakia is described within the framework of the first (1919-1939) and the second (1945-1992) Czechoslovak Republics, and we discuss the development of Marketing, HRM, and other consulting in Slovakia. We also discuss clients' opinions of consultants in the light of an empirical research project carried out in 2018.
\end{abstract}

Keywords: consulting, development, Czechoslovakia, Slovakia

DOI: http://dx.doi.org/10.15549/jeecar.v7i2.390

\section{INTRODUCTION}

Management consulting as a business service appeared in the United States about 130 years ago during the second Industrial Revolution. It has since spread over the whole world. With the start of mass production and the growing size of industrial and railroad companies, there was an increasing need for experts who were able to support business leaders in organizing processes and people effectively. Due to the enormous distances involved, the rapid expansion of railroads in America brought about 
the creation of huge railroad companies. For example, the Pennsylvania Railroad Company already had 110,000 employees in 1890 . Thanks to rapid industrial development, the productivity of capital goods increased dramatically, but, at the same time, labor productivity did not change. Organizing work and improving employee productivity was the focus of scientific management at that time. According to Kipping and Clark (2012), the first representatives of scientific management can be considered as the forerunners of management consulting.

Today, there is hardly any business area that cannot be linked to consulting activities (Gross et al., 2009; Anyakoha et al., 2019). Over the past few years, meeting customer needs has shaped the areas of management consulting (e.g., strategy, HRM, business, operational, project, I.T., Big Data, etc.). Today's consulting firms organize their business around these subdivisions, specializing in one or more of them. Research into the size and characteristics of the Slovakian management consulting market was conducted by the largest research networks (Source Global Research and IBIS). In contrast, local research on this topic has been quite rare. Our research, launched in September 2018, will hopefully help close that gap.

In this article, we explore the emergence and development of Slovak management consulting practice by studying literature on the subject, mainly Slovakian and Czech. At the same time, we approach current trends by analyzing data from recent global and regional surveys. Following the presentation of the Slovakian management consulting market based on secondary data, we show the results of our 2018 survey.

\section{ABOUT MANAGEMENT CONSULTING Concept of Consulting}

Management consulting provides "knowledge-based inputs" to guide and strengthen the business processes of organizations (Miles, 2005; Greiner \& Metzger, 1983). Specially trained professionals provide consulting to various organizations, thereby assisting the client organization in identifying and analyzing management problems objectively and independently and assisting with implementation on request (Kipping \& Clark, 2012; Niedereichholz \& Niedereichholz, 2012; Brooks \& Edward, 2014).

According to Kubr (1996), consultants help organizations achieve their goals, identify and solve problems, identify new opportunities, acquire new skills, and implement change (Block, 1981; Markham, 1999; Kipping \& Clark, 2012; Poór, 2016, Žul'ová et al., 2019). Brooks and Edwards (2014). Schein $(2002,2016)$ and Cohen (2018) classify consultants in three broad categories:

1) Expert Consultants: These professionals, based on their expertise and experience, recommend solutions, convince clients of their correctness, and help with implementation.

2) Process consultants: help their clients find solutions by stimulating their client's creativity by facilitating methods. Their services are most often implemented through interactions that require group and individual collaboration.

3) Inquirer or humble consultants: In this case, the client and the consultant, who work together as partners to achieve the desired outcome, are required to achieve the goals. Some professionals also classify this type of consulting as agile consulting.

\section{Emergence and Development of Global Management Consulting}

As we mentioned above, today, consulting covers almost every area of business. Its center of gravity orientation has changed significantly over the past decades (Fink, 2004; Czerniawska \& May 2004). From its inception to the present, the development of consulting can be discussed in several divisions.

The development of consulting can be linked to five major trends. While the representatives of the classical tendency were primarily technocrats, the representatives of the neoclassical tendency were social scientists, psychologists, and sociologists. In management, specialists from the technical and technological fields, representing the engineering approach, have developed trends with strong rational thinking. In contrast, those from the humanities 
and social sciences have developed trends that focus on human behavior and human factors. Accordingly, there are two distinct scientific paradigms in leadership thinking, the former of which can be called "objective rationality" and the latter "humanism." These two viewpoints may be identified throughout the history of management science. With the transformation of management, organization and strategy came to the forefront. The main drivers of this trend were the increase in company size, the spread of decentralization, and portfolio-based planning.

Customer demand for advisory services is always an important prerequisite for the globalization of consulting firms, but the existence of strong demand alone is not enough to guarantee foreign expansion. Most companies have set up appropriate filters and criteria to prepare for expansion decisions to establish new offices abroad. Some companies formally document these criteria while others rely on the tacit knowledge of senior management to make their expansion decisions. Many authors (Kipping \& Wright, 2012; Boussebaa \& Faulconbridge, 2019) agree that consulting firms play a very important role in the unfolding of globalization.

The information and communication (IT/ICT) revolution that has evolved over the last decade has significantly influenced the development of consulting. At this stage of development, the management consulting departments of major audit firms became critical actors (such as Pricewaterhouse \& Coopers, Deloitte \& Touche, Ernst \& Whiney, Arthur Young, KPMG, etc.) as well as prominent players in the I.T. sector, EDS, CSC, Capgemini, IBM, and Tata companies. Thanks to robotics and artificial intelligence (A.I.), fifth-generation consulting is already knocking on the imaginary door of the industry. For a long time, this industry was characterized by uninterrupted development. Double-digit growth was not infrequent (Bronnenmayer et al., 2014).

Moreover, it was unprecedented that advisors were able to prosper despite the downturn or stagnation of the economy. The 2008-2009 crises was the first major economic crisis where the same crisis hit consultants as their clients. Downsizing and the closure of previously prosperous businesses were not uncommon in this industry either. Today, the situation has changed, and once again, there is double-digit growth in this industry, which employs more than 2.4 million people worldwide, generated $\$ 630$ billion in revenue in 2018 (IBIS, 2019). Figure 1 summarizes the main waves (schools) in the development of consulting that we have briefly explained above.

Figure 1: Development of Management Consulting industry.

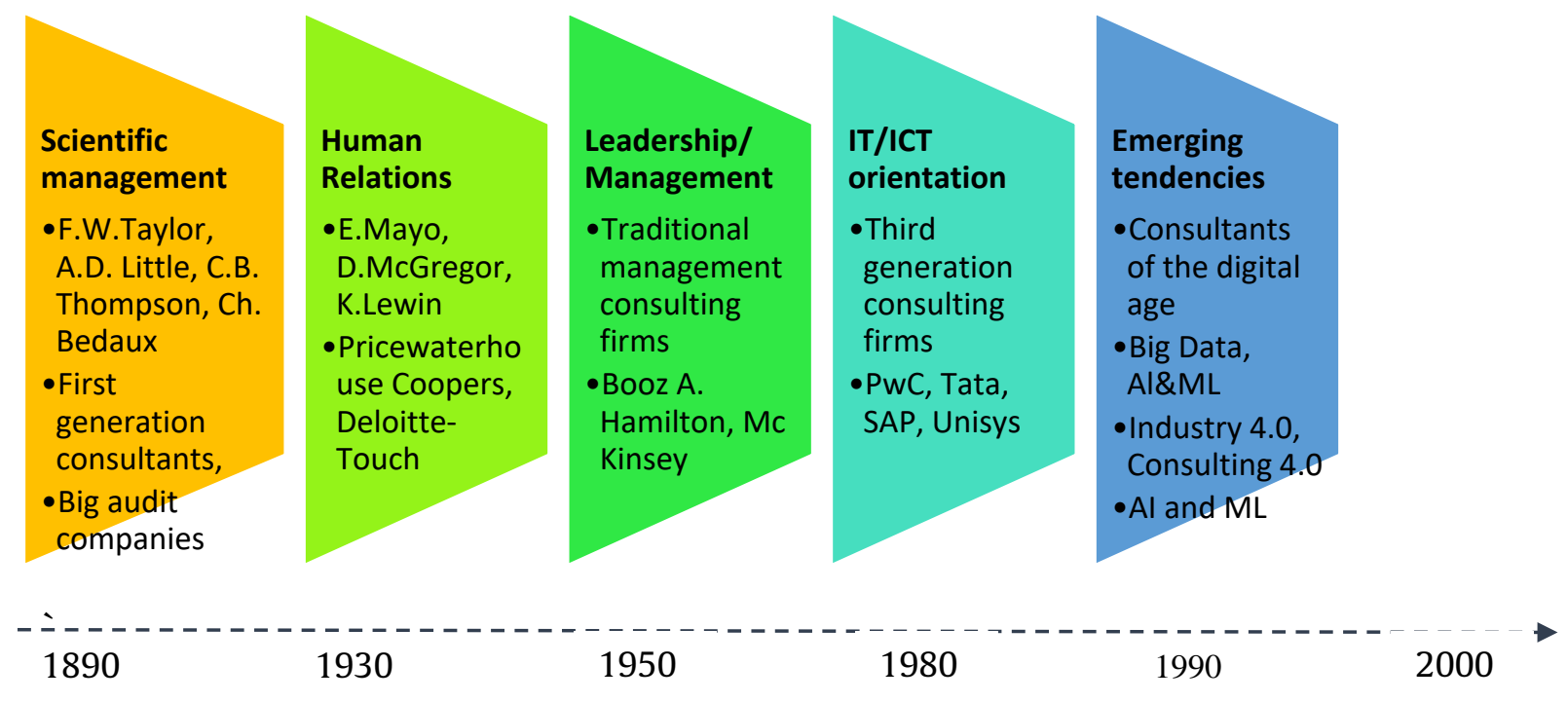

Source: Authors' own compilation. 
Had we asked high school students from different Eastern European countries 25-30 years ago about what kind of career or profession they wanted to choose, they would have answered: doctors, lawyers, athletes, travelers, teachers, but only in the rarest case would we have heard management consultants. At that time, the general public in these countries knew very little about this field. Due to the level of economic development of a particular country in the region and the different degree of centralization of the previous economic and political system, there are smaller or larger differences in development in the consulting practices of the various Central and Eastern European countries (Poór et al., 2018). The development outlined above has been greatly influenced by the major socio-economic transformation, privatization, E.U. accession, and, last but not least, export-driven economic development (Jirasavetakul \& Rahman, 2018). in this region, including Slovakia.

\section{DEVELOPMENT OF MANAGEMENT CONSULTING IN SLOVAKIA}

\section{Consulting in the Czechoslovak Era}

Between the two world wars, Czechoslovakia, which included today's Slovakia, was characterized by German-style corporate governance at its emergence. However, the leadership of the country, founded in 1919, was mainly oriented towards Western Europe and Anglo-Saxon countries. Therefore, and due to the national liberal climate, Czechoslovakia was the state where they were most receptive to new ideas of economic governance. It is no coincidence that the ideas of Frederick F. Taylor, Henry Ford, or Henri Fayol were also read in the Czech language (Ford, 1924; Taylor, 1931; Fayol, 1931). As we described in the previous paragraph, scientific management was an important concept in this era. This was no different in the Czechoslovak Republic (19191939).

There was also an institutional framework for work organization research in Czechoslovakia. The Masarykova Akademie Práce was founded in 1920 with six professional departments whose goals included the application of the Taylor model and the scientific management of work. Study visits abroad were organized for
Czech and Slovak engineers and technicians in these countries to learn more advanced working methods (Seilerová, 2019). It helped organize the visits of outstanding science and technology representatives in the Czech Republic, and last but not least, supported the introduction of Ford production methods in the Czech Republic (Nespor, 2017). The economic crisis of 19291930 caused a major break in the life of the institute, and due to the lack of financial capacity, some of its institutes had to be closed. Later this organization became weaker in American orientation, and then it started to open towards Portuguese, Soviet and German, that is, the étatist method. The institute operated until 1952 when it merged into the Czechoslovak Academy of Sciences (Mišková, Franc \& Kostlán, 2010). Another institution with a similar orientation was the Czech Standards Association, established in 1923. The strength of Czech scholarship is demonstrated by the fact that Prague was also the venue for the first conference on the scientific background of management work (Prague International Management Congress) in 1924, and the first international standardization congress was also held in the Czech capital in 1928.

Setting about theoretical methods into practice was mainly addressed by technically qualified professionals. Among the most important theoretical representatives of scientific work, management are the names of Špaček and Verunač. Tomáš Bat'a's shoe factories were some of the most successful in applying the theory, and their productivity was even higher than that of the American plants (Prücha et al., 2004).

The history of the Central and Eastern European countries of the 20th century was determined by a series of profound shocks, including the introduction of the socialist social and economic system between 1945 and 1948 and its subsequent demolition after 1989. In the socio-economic command system, a centralized model of consulting was implemented. The central determinants of the system were central economic management and isolation. Consequently, many economic innovations were not able to take root in the region, including Czechoslovakia, or could not prevail because of the special features of the system; these 
included several types of consulting. In general, prior to the political changes in the late 1980s, in most Eastern European countries, consultancy services were provided by state-run research institutes, universities or departments of individual ministries. In most countries, central institutions for management consulting were established with the help of the International Labor Organization (ILO) or UNIDO, the professional body of the UNO (Kubr, 1996). In these countries, the features of modern management consulting under the previous system were only traces. Approaches related to the previously mentioned trend of scientific management were the most characteristic (Poór, 2016).

Kubík (1969, p. 70) described the rationalization process as: "Governance serves as a key to increasing the efficiency of the workshop, the office, the plant, the company and the national economy as a whole." The consultant role was performed by external scientific institutions, which were also imbued with the ideology of the time, although there was no doubt that they intended to correct. Among them, the Slovak Technical College, the Faculty of Economics and Management of the College of Economics, the Czechoslovak Institute of Labor Research, and the Institute of Management must be highlighted. Koucký and Říha (1972) mention a total of 29 such institutions.

Analyzing the literature of the period, it is clear that they did not discuss the processes then taking place in the capitalist countries; the maximum concession was that classic cases of the first half of the $20^{\text {th }}$ century were briefly referred to. An exception to this was when, in addition to Soviet, East German, and Yugoslav experiences, Japanese practice was mentioned (Linczényi, 1970).

The emergence of 'market-based' consulting dates back to the late 1980s. In Czechoslovakia, when they wanted to put into practice the deepening of new scientific and technical knowledge, they still referred to the Congress of the Communist Party of Czechoslovakia and the decisions of the Central Committee. Consulting was then defined as follows: "Consulting is a specific professional activity of management that assists managers in solving their specific management problems and introduces the most progressive experience into the institutions" (Šimončič 1988 p. 13).

Even during the Socialist period, a national symposium was held in Prague with the participation of foreign lecturers, with the title "Preparation and Consulting for Strategic Management and Innovation", which one of our co-authors participated in with his lecture (Poór, 1990). Dozens of participants also came up with a market-based interpretation of consulting. Lipták (1989), a representative of the Bratislava Institute of Management, stated that "in the industrialized countries of the world management consulting is a very diversified advanced activity" and then went on to say that there was no specific institutionalized consulting in Czechoslovakia.

\section{After the Establishment of Slovakia}

In 1989, the countries of the Central and East European region opened the way for the adoption of Western-style management principles and methods, which could be realized through the inflow of foreign working capital. For countries having undergone the change of regime, foreign direct investment played an important role in the structural reconstruction and modernization of the transition economies (Fábián, 2010). The advance of consulting as an independent business service took place simultaneously in two strands. Large international consulting companies are starting to establish themselves in the area, after which local specialized firms emerged, usually founded by formerly experienced professionals who were then self-employed. The first longstanding international consultancy firms came to Slovakia in 1991, including Ernst \& Young, KPMG, PricewaterhouseCoopers, and others. Initially, the consulting firms mainly helped the expansion of large international companies in Slovakia, and in many cases, the clients were followed by the consulting firms in the region. As the Czech and Slovak markets share many of the same motifs and the languages of the two peoples are almost the same, many consulting firms did not establish a separate unit in Bratislava after settling their headquarters in Prague (Fobel, 2013, Hanuláková \& Paráková, 2013a-c; 2014) 
In Slovakia, as in many countries around the world and in other CEE countries, consulting is not legally regulated. Anyone can set up a consulting firm without the need for a special consulting qualification, provided they meet the general economic and financial requirements for starting a business.

As a result of the slowdown in transformation, Slovakia, compared to other post-communist countries, performed poorly in restructuring the economy. That is why foreign and domestic investment in knowledge-based sectors was delayed and much more modest than in other countries in the region and is still lagging behind. This further strengthens the country's dependence on lower value-added, laborintensive sectors. The country's export products are mainly simple, low-processed, low-valueadded products whose export competitiveness is primarily determined by the price factor.

In Slovakia, the development of a purposefully investor-friendly entrepreneurial environment began in 1998. The program of the new
Dzurinda government (a coalition of two centerright and one center-left party) aimed at eliminating the integration gap and the recovery of the crisis-hit economy. It was achieved through deep, comprehensive reforms and restructuring of the macro environment. Thanks to its effective economic policy, it was able to lift the country from a "lagging behind" position to one in the forefront; in 2004, it succeeded in joining the European Union together with the other V4 countries and six different states. Government policy measures primarily targeted the banking-, tax-, pension-, health-, social systems, and labor market (Mikloš, 2008). In the following years, the inflow of foreign working capital accelerated significantly.

It is important to note that the use of consulting is high in countries where economic development and innovation are particularly high, and where regional culture has a relatively low degree of uncertainty avoidance, (Barthelemy, 2019).

Table 1: Cultural dimensions by Hofstede and the share of consultancy expenditure in the country's GDP.

\begin{tabular}{|c|c|c|c|c|c|c|c|}
\hline \multirow[b]{2}{*}{ Countries } & \multicolumn{6}{|c|}{ Cultural dimensions by Hofstede } & \multirow[b]{2}{*}{$\begin{array}{l}\text { Estimated } \\
\text { share of } \\
\text { consulting in } \\
\text { the country's } \\
\text { GDP }\end{array}$} \\
\hline & $\begin{array}{l}\text { Power } \\
\text { Distance } \\
\text { Index } \\
\text { (high } \\
\text { versus } \\
\text { low) } \\
\end{array}$ & $\begin{array}{c}\text { Individualis } \\
\text { m Versus } \\
\text { Collectivism }\end{array}$ & $\begin{array}{l}\text { Masculinity } \\
\text { Versus } \\
\text { Femininity }\end{array}$ & $\begin{array}{l}\text { Uncertainty } \\
\text { Avoidance } \\
\text { Index (high } \\
\text { vs. low) }\end{array}$ & $\begin{array}{c}\text { Long- vs. } \\
\text { Short-Term } \\
\text { Orientation }\end{array}$ & $\begin{array}{l}\text { Indulgence } \\
\text { Versus } \\
\text { Restraint }\end{array}$ & \\
\hline $\begin{array}{l}\text { Slovak } \\
\text { Republic }\end{array}$ & 100 & 52 & 100 & 51 & 77 & 28 & $0,25^{*}$ \\
\hline $\begin{array}{l}\text { Czech } \\
\text { Republic }\end{array}$ & 57 & 58 & 57 & 74 & 70 & 29 & 0,33 \\
\hline Hungary & 46 & 80 & 88 & 82 & 58 & 31 & 0,31 \\
\hline Poland & 68 & 60 & 64 & 93 & 38 & 29 & 0,10 \\
\hline Germany & 35 & 67 & 66 & 65 & 83 & 40 & 0,71 \\
\hline Switzerland & 34 & 68 & 70 & 58 & 74 & 66 & 0,25 \\
\hline Austria & 11 & 55 & 79 & 70 & 60 & 63 & 0,74 \\
\hline
\end{tabular}

Source: Barthélemy, J. (2019). The Impact of Economic Development and National Culture on Management Consulting Expenditures: Evidence from Europe and North America. European Management Review, July, 1-11. https://doi.org/10.1111/emre.12352 (Downloaded: 15 July, 2019)

The work of Hofstede (1980) can be applied to consulting. The uncertainty avoidance index in Slovakia - see in Table 1 - is the lowest in the countries of the region, and even in comparison with the countries of DACH (Germany, Austria, and Switzerland). Avoidance of uncertainty is highest in Polish society (93), but also relatively high in Austria (70) and Germany (65). 
However, it is noticeable that the power distance in Slovakia is by far the highest (100), followed by Romania with a similarly high level (90). On the other hand, in economically highly developed DACH countries, power distance is very low $(35,34,11)$. In Slovakia, therefore, the tendency of society to avoid uncertainty does not inhibit either entrepreneurialism or the introduction of new things and the use of consultants.

\section{Current Trends in the Slovak Management Consulting Market}

Data on the size and other parameters of the Slovak management consulting market can be found in the results of CEE regional surveys of global research centers. Unfortunately, Slovakia has not been included in the survey of the European Federation of Management Consulting Associations (FEACO) which has been carried out since 1994.

The global management consulting industry's annual revenue in 2018 was $\$ 634$ billion (IBIS, 2019 ), $28 \%$ or $\$ 177.5$ billion of which was generated by the European consulting industry.

According to Source Global Research's 20152017 data, the management consulting industry of the CEE region (Hungary, Poland, Slovakia, Czech Republic and Romania) generates \$3.5 billion, $8 \%$ of which can be connected with Slovakia. Figure 2 illustrates the distribution of the market in the region.

Figure 2: Geographical distribution of CEE management consulting market.

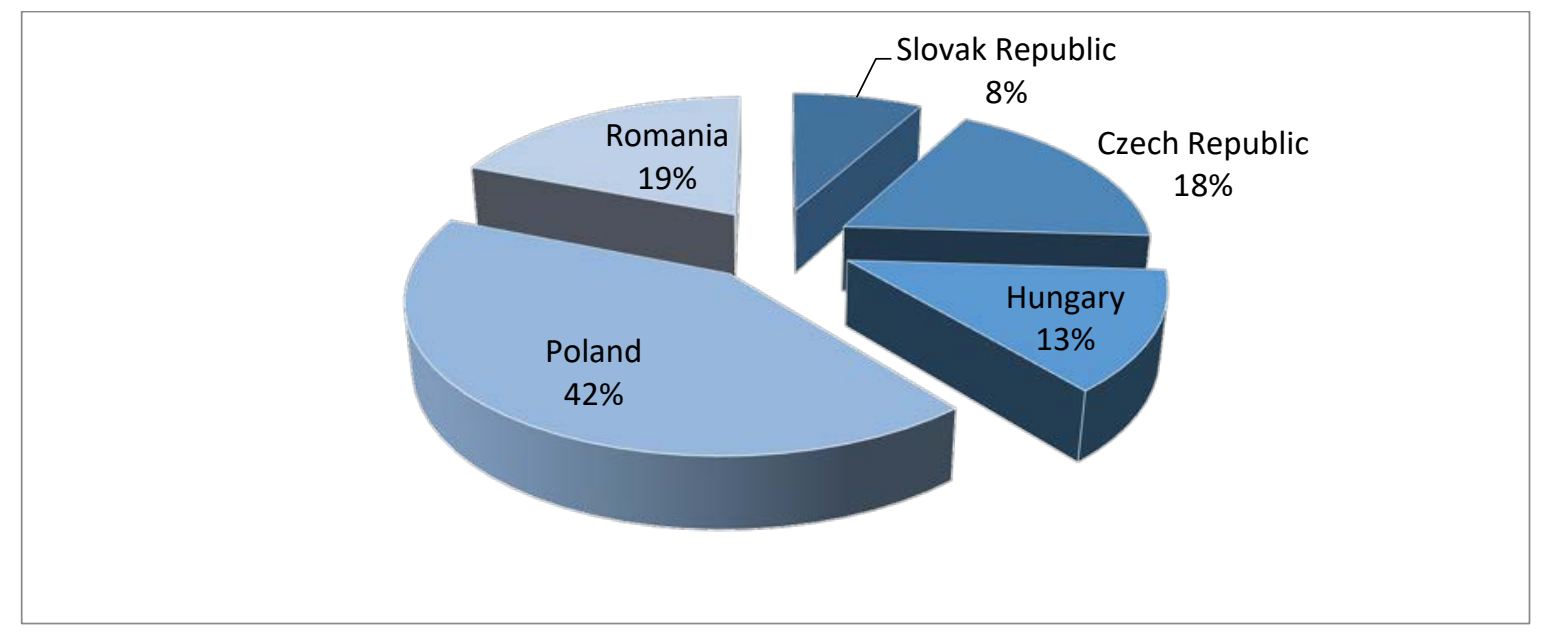

Source: Authors' own compilation according to Source Global Research, 2015-2017.

There are now countless representatives of the consulting industry in the Slovak market, including local subsidiaries of the largest global consulting firms, domestic consulting firms that have grown continuously over the last 20-25 years, as well as micro and macro firms and freelance consultants. Today we can hardly find an area of business life which cannot be connected to some kind of consultancy business. As reported, the Slovak consulting market accounts for $8 \%$ of the CEE region's consulting market, with annual sales of $\$ 280$ million. PwC Slovakia is the largest profit-generating consulting firm with annual sales of $€ 47$ million. PwC has been active in the Slovak market since
1991, operating two offices, one in Bratislava and one in Košice - and currently employing 770 people. Forty-four of PwC Slovakia's clients are companies on the Trend Top 200 list. Public sector consulting in this region, including Slovakia, is growing very slowly, with a very low share of GDP in relation to the European average.

There are many articles on the Slovakian consulting market in daily newspapers and weekly periodicals, but no scientific survey of this business segment has yet been published. That is why the researchers of the Faculty of Economics of the Pan-European University of Bratislava and the Faculty of Economics of the J. 
Selye University of Komárno undertook the following survey.

\section{EMPIRICAL RESEARCH}

\section{About the research}

With our empirical survey, we try to answer the question of how widespread the involvement of external consultants in Slovak businesses and institutions is and how satisfied respondents are with the consulting services they use. The research was conducted in the autumn of 2018 throughout Slovakia. Participation in the survey was voluntary, and the companies surveyed were randomly included in our survey. With a response rate of $24 \%$, we received 194 valid, completed questionnaires, which were processed by descriptive statistical methods. In one organization, we collected questionnaire responses from only one respondent. We completed our questionnaire based on previous similar surveys in Hungary (Poór-Iliás, 2015) and similar research conducted by the European
Management Consulting Association (FEACO) (2008-2013).

Our questionnaire contained 21 questions, seven of which related to the responding organization and person. In the remaining 14 questions, we examined the acceptability, use, and non-use of consulting.

\section{THE RESEARCH SAMPLE}

Roughly half (48\%) of the companies surveyed have already employed external consulting services, and this was covered in the first part of our questionnaire. In the second part, we asked for the opinions of companies with no such experience. As a result, the answers were evaluated based on different numbers of items.

A substantial number of respondents (41\%), belonged to the SME category, while organizations with 1000 or more employees are represented in the survey by nine percent. The size distribution of the participating organizations is illustrated in Figure 3 below.

Figure 3: Participating organizations by size.

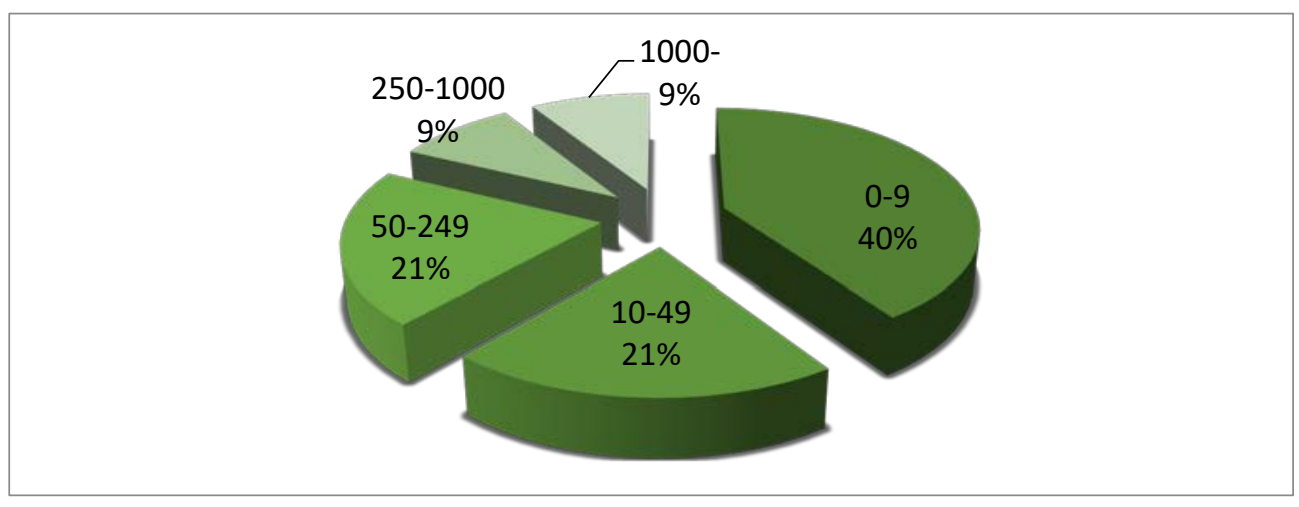

Source: Authors' own compilation.

Most respondents came from the Bratislava district, which is because Bratislava is home to the largest number of companies, so most of the randomly selected organizations have their headquarters there. Many of the respondent organizations (68\%) were domestically owned, and $17 \%$ were foreign-owned companies. The public sector represented $14 \%$ of the respondents. Most of the respondent organizations operated in the services sector, followed by manufacturing, trade, and the public sector.

\section{Reasons for employing external consultants}

The largest group of organizations surveyed (43\%) rely on external consultants since they believe that these professionals have specialized knowledge that can create value for their company, while $40 \%$ rely on external professionals because they think their company is too small to have their own expert for every 
area. Almost one-third of responding organizations hire consultants in specific cases such as crisis, acquisition, restructuring, major investments, etc., $26 \%$ of respondents require the services of external consultants for searching for cost-cutting solutions, and only $10 \%$ seek external expertise because they are required to do so for various tenders or applications, in respect of bank loans or international grants. Less so, only nine percent of respondents said they used external consulting services because of legal obligations.

Respondents were asked to rate on a fivepoint scale, how satisfied they were with the external consultancy service they use. With our scale, one means least satisfied and five means fully happy. The average score of 3.88 shows that respondents are more or less satisfied with the service they have received. All of the answers received were between 3 and 5, and so there were no respondents who were completely dissatisfied with the consultancy service they had purchased.

We wished to know how respondents feel about the consulting service they received beyond what they thought about its usefulness. We found that $12 \%$ of respondents were unable to implement the consultant's proposal, and 7\% said they could not work well with the consultant. Relatively many, $40 \%$, of the respondents, believe that the value and price of the service they received were not in balance.

We also wanted to know the areas at which the organizations typically use external consultants. The respondents gave efficiencyenhancing and finances on the first place. Figure 4 illustrates the areas in which respondents typically use external consultants.

Figure 4: Areas of the application of an external consultant.

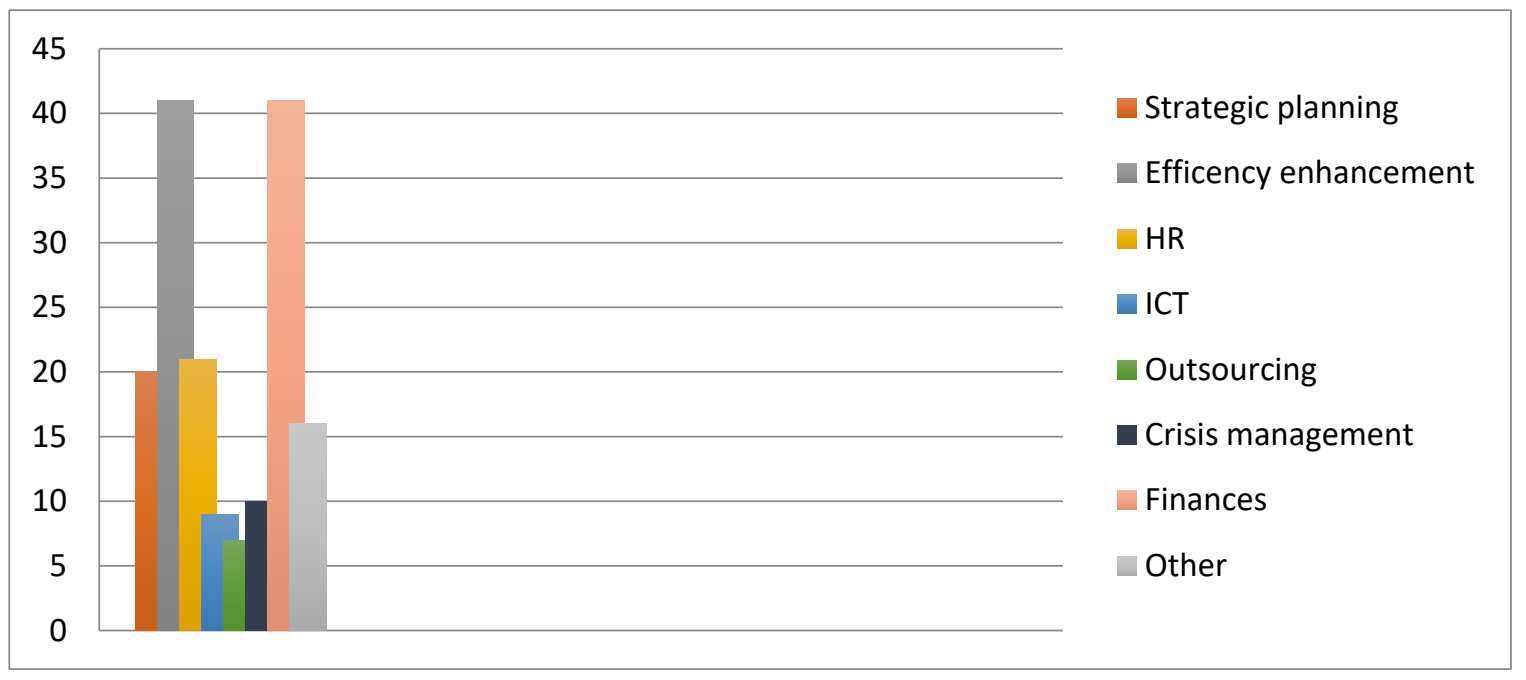

Source: Authors' own compilation.

Only $17 \%$ of the organizations surveyed prefer large multinational consulting companies, while the remainder of the respondents instead searches for sole local proprietors (56\%) or local small businesses when needing a consultant.

We asked the participants to place their selection criteria on a Likert scale, where 1 is the least important and 5 is the most important. According to the survey results, the main criteria are the consultant's references, prior experience, and the complexity of the service provided. This is followed by personal acquaintance, short deadlines, and the cost of the service. The least important factors include the location and size of the consultant company and the advertisements of the consultant.

Respondents who have not used external consultants so far were asked about their intentions for the future. When asked for what reasons they are planning to use consulting, 15\% of respondents said they need it because of the expectations of various institutions (banks, 
international grants, etc.), $26 \%$ of respondents plan to engage external consultants because the company is too small to have its own internal staff in every area, and 26\% would use external consultants in exceptional cases (crisis, restructuring, major investment).

When asked about the basis on which they choose the right adviser, many respondents (40\%) consider the recommendation of their acquaintances to be the most significant, and the proportion of those who would select by tender is similarly high. $19 \%$ of the respondents rely on the marketing appearance of the consultant. 23\% of companies with no previous experience with consultants prefer large, international companies, while $76 \%$ prefer small domestic firms or freelance consultants.

Responding organizations with no previous experience with consultants were also asked to rate the listed selection criteria on a scale from 1 to 5, where 1- means not at all important and 5very important. The selection criteria of our respondents in relation to the consultant they wish to select are illustrated in Figure 5.

Figure 5: Criteria for selecting a consultant.

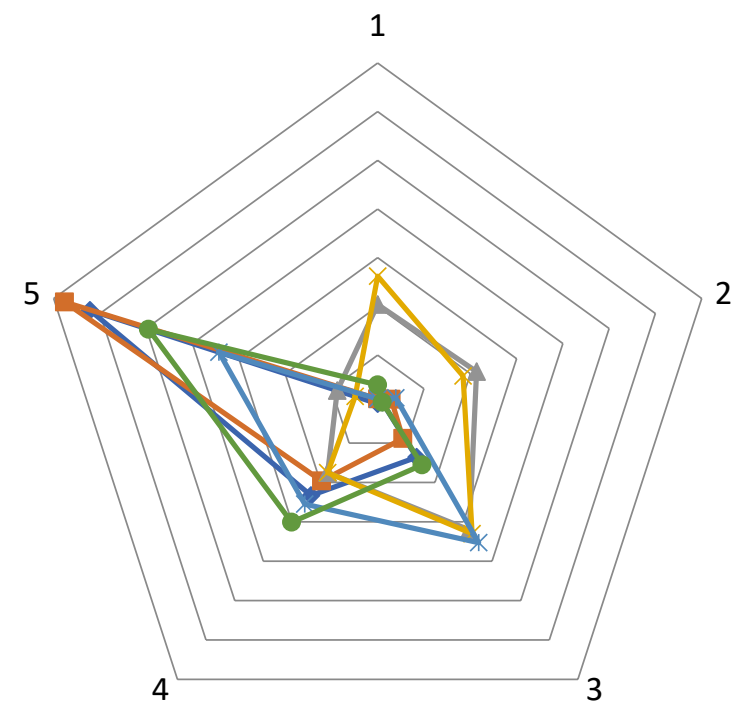

$\sim$ Reputation of the consultant

- Previous professional relationship

- Consultant's PR

$\star$ Headquarter's of the consulting company

* Price of the service

- Complexity of the service

Source: Authors' own compilation.

\section{CONCLUSIONS}

The formation and development of Slovak consulting were greatly influenced by the country's relationship with former Czechoslovakian state. The fact that there are no language barriers has helped the survival of the Czechoslovak tradition, so the companies are able to provide services in both countries after the split. The parallel development is facilitated by the fact that the Slovak market is smaller than the Czech market so that the largest international service providers not only open their office in the Czech capital Prague but also serve their Slovak clients there (McKinsey,
Boston Counseling Group, etc.). As the development of the Slovak market economy slowed down in the 1990s, the Czech Republic, like in old Czechoslovakia, serves as an example for Slovakia and continues to have an impact on Slovak economic development.

The Slovak consulting market is a growing and developing market, which has been established in Slovakia through the inflow of foreign working capital opening their markets to international players. Currently, numerous international and domestic consulting organizations specializing in all areas of the economy exist. The consulting industry's most 
profitable customer sectors are the financial services sector, industrial production, and media and telecommunications. The majority of Slovak companies (99\%) are SMEs, the vast majority (87\%) being domestically owned. Large multinational companies typically outsource the labor-intensive operations to Slovakia, the strategic decisions having been taken in their headquarters. The number of R\&D centers in the country is negligible, and Slovakia is among those countries lagging behind the E.U. and the OECD in terms of innovation.

Our survey conducted among Slovak companies included 194 organizations across the country. Nearly half of the responding organizations have had previous experiences with external consultants, and those who have not yet done so also have a positive attitude towards such services.

In this article, we do not attempt to present all the survey results or to explore deeper relationships; we only provide insights into the prevalence of consulting and customer satisfaction of consulting services' clients, which are designed to map current market conditions. Due to the low number of respondents, our survey cannot be considered as a representative, but, in spite of that, it is still appropriate to draw cautious conclusions, since among the respondent organizations there are the largest organizations as well as the smaller and intermediate-sized entities in proportions representative of the Slovak market. The three sectors (private, public, and non-profit) are also represented appropriately.

The responding organizations are quite satisfied with the consultancy services they purchased, but there is a relatively high proportion (40\%) of organizations that strongly question the value for money of the service, and $12 \%$ were unable to implement the consultant's proposal. The vast majority (82\%) of responding organizations is SMEs, and only $17 \%$ are foreignowned. This is exactly the percentage (17\%) of organizations that chose the services of the major international consulting companies.

The remaining $83 \%$, the vast majority of respondents, instead choose a local small business or a local individual consultant if they need management advice. According to the survey, the most common reason for a Slovak company or institution to use management consulting is to increase efficiency and finances (investments, project financing, improving liquidity, etc.).

Soon, the challenges posed by the increasing pressure of the digital revolution and the scarcity of the available workforce in Slovakia will provide a new impetus. We are about to continue our research with an expanded survey addressing a more significant number of organizations, aiming to explore the Slovak consulting market more deeply. We are aware that in such an article, we cannot answer all the questions related to the development of consulting in Slovakia. The purpose of this article was to integrate the development of Slovakia into the global and regional development of the sector. Further research aims to compare trends in Slovakia with similar or different trends in other countries in the region.

\section{REFERENCES}

Anyakoha, C. (2019). Job analysis as a tool for improved organizational performance of SMEs in Lagos, Nigeria. Central European Journal of Labour Law and Personnel Management, 2 (1), 7-16. http://doi.org/10.33382/cejllpm.2019.02.01

Barthélemy, J. (2019). The Impact of Economic Development and National Culture on Management Consulting Expenditures: Evidence from Europe and North America. European Management Review, July, 1-11. https://doi.org/10.1111/emre.12352 (Downloaded: 15 July, 2019)

Block, P. (1981). Flawless Consulting. San Francisco: Pfeiffer Company.

Boussebaa, M. and Faulconbridge, R.J. (2019). Professional service firms as agents of economic globalization: A political perspective. Journal of Professions and Organization, 6, 72-90.

Bronnenmayer, M., Wirtz, B.W. and Göttel, V. (2014). Succes factors of management consulting. Review of Management Science, 10 (1), 1-34.

Brooks, A. K. and Edwards, K. (2014). Consulting in Uncertainty - The Power of Inquiry. New York: Routlidge. 
Cohen, A.W. (2018). Consulting Drucker. New York: LID Publishing.

Curuksu, J.D. (2018). Analysis of the Management Consulting Industry. DataDriven. Management for Professionals. Cham: Springer, pp. 1-16. https://link.springer.com/chapter/10.1007/9 78-3-319-70229-2_1 (Downloaded: 2 Ju1y, 2019)

Czerniawska, F. and May, P. (2004). Management Consulting in Practice. London: Kogan Page.

Eastern European consulting industry grows 7\%, market worth $€ 1.4$ billion (2018).

Consultancy.eu. https://reports.sourceglobalresearch.com/re port/download/3028/extract/The-EasternEurope-Consulting-Market-in-2017 (Downloaded: 25 July, 2019)

1. Fábián, E. (2012). Capital investments in Hungary. (In Hungarian) http://unipub.lib.unicorvinus.hu/569/1/kozg_2012n1p111.pdf (Downloaded: July 20, 2019)

FEACO Annual Report 2012/2013. (FEACO), Brussels: Federation of European Consulting Associations.

FEACO annual research reports, 1994-2018. http://www.feaco.org/site-page/feacoannual-survey-european-mc-market. (Downloaded: 15 July, 2019).

Fink, D. (2004). Management Consulting 2004 Trends and Kompetenzen in Management Beratung. Bonn: Vahlen.

Fobel, P. (2013). Social importance and professional mission of ethical consulting (In Slovak) In Fobel, P. et al.: Organizational ethics and professional ethical consulting. (In Slovak) Žiar nad Hronom, 8-25.

Ford, H. (1924). My life and my work. (In Czech) Praha: Sfinx. .

Fritsch, M and Brezinski, H. (1999) Innovation and technological change in Eastern Europe: pathways to industrial recovery. Cheltenham: Edward Elgar Publishing Limited,
Greiner, L. E. and Metzger, R. O. (1983). Consulting to Management. New York: Englewood Cliffs.

Gross, A., Poór J., and Solymossy,E. (2009). The changing outlines of western management consulting. (In Hungarian) Marketing and Management, 44 (4), 20-32.

Hanuláková, E and Paráková, R. (2013a). Economic and legal aspects of consulting. (In Slovak) Studia Commercialia Bratislavensia, 6 (22), 188-197.

Hanuláková, E. and Paráková, R. (2013b). Approaches to the classification of consulting activities. (In Slovak) Ekonóm, pp. 46-57.

Hanuláková, E. and Paráková, R. (2013c). Trendy a perspektívy poradenstva (Trends and perspectives of cnsulting). (In Slovak) Vedecké state Obchodnej fakulty II. Ekonóm, Bratislava, pp. 171-178.

Hanuláková, E. and Paráková, R. (2014). Use of consultancy in solving environmental challenges of business activity. (In Slovak) Studia commercialia Bratislavensia, 7 (26), 186-196.

Hofstede, G. (1980). Culture's Consequences: International Differences in Work-Related Values. Beverly Hills (C.A.): Sage.

IBIS World Report (2019) Industry trends, global industry reports https://www.ibisworld.com/industrytrends/global-industry-reports/businessactivities/management-consultants.html (Downloaded: 26 July, 2019)

Jirasavetakul, L-B. F. and Rahman, J. (2018). Foreign Direct Investment in New Member States of the E.U. and Western Balkans: Taking Stock and Assessing Prospects. Washington: International Monetary Fund

Kipping, M. and Clark, T. (2012). The Oxford Handbook of Management Consulting. Oxford: Oxford University Press.

Kipping, M., and Wright, C. (2012) Consultants in Context: Global Dominance, Societal Effect and the Capitalist System. In: Kipping M., Clark T. (eds) The Oxford Handbook of Management Consulting, pp. 165-85. Oxford: Oxford University Press 
Koucký, J. and Říha, L. (1972). Complex socialist rationalization. (In Czech) Praha.

Kubík, J. (1969). Basics of rationalization practice. (In Czech) Praha: Institut rízení.

Kubr, M. (1996). Management Consulting a Guide to the Profession. Geneva: International Labor Office.

Leščišin, M. and Stern, J. (1983). Organization and quality management. Selected chapters). (In Czech) Praha: Vysoká škola ekonomická.

Linczényi, A. (1970). Comprehensive quality management. Library Rationalization and Management, Vol. $7^{\text {th }}$ (In Slovak). Bratislava: Práca.

Lipták, F. (1977). Rationalization plan of the company. (In Slovak) Bratislava: Práca.

Lipták, F. (1989). Functions of consulting in management. In Procházka, V., Ždímal, M., Sagan, V. and Landa, O., (eds.): Preparation and consulting for strategic management and innovation, national workshop with international participation. (In Czech) Praha, 14.-16 February 1989, P1-P7.

Maister, D. (1993). Managing Professional Service Firm. New York: Free Press.

Markham, C. (1999). The Top Consultant, Kogan Page, London.

Masaryk Academy of Labor https://www.mua.cas.cz/en/masarykacademy-of-labor-masarykova-akademieprace-685 (Downloaded: 29 August, 2019)

Miles, I. (2005). Knowledge-intensive business services: prospects and policies; Foresight, 7 (6) , 39-63.

Mîšková, A., Franc, M. and Kostlán, A. (eds.) (2010). Bohemia docta. Praha: Academia.

Nešpor, R.Z. (2017). Masaryk Academy of Labor (1920-1952). (In Czech) https://encyklopedie.soc.cas.cz/w/Masaryko va_akademie_pr\%C3\%A1ce (Downloaded: 29 August, 2019)

Niedereichholz, Ch. and Niedereichholz, J. (2012). Das Beratungsunternehmen. München: Oldenbourg Verlag,

Plunkett, J. W. (2018). Major trends affecting the consulting industry. In: Plunkett's
Consulting Industry Almanac 2018. Houston: Plunkett Research, 6-21.

Poór, J. (1990). Notes for a Brief History of the Hungarian Consulting Industry. In: Second European Management Congress. East Meets West, CECIOS European Council of Management, Prague, October 22-25. 1990. (Conference proceeding) pp. 61-62

Poór J., Gross, A. and Roberson, M. (eds.) (2003). Management Consultancy in an Eastern European Context: in Association with FEACO. Budapest: KJK-KERSZÖV Publishing House.

Poór, J. and Milovecz, Á. (2011). Management Consulting in Human Resource Management: Central and Eastern European Perspectives in Light of Empirical Experiences. Journal of Service Science and Management. 8 (1), pp. 300-314.

Poór, J. (Ed.) (2016) Management consulting handbook. ( $2^{\text {nd }}$ edition) (In Hungarian) Budapest: Akadémiai Publishing House.

Poór, J. and Wood, G. et al. (2018). The Changing Role of External Providers of HRM: Empirical Evidence from Consecutive Cranet Surveys In: Venegas, B. et al. (eds.) Personalmanagement Internationale Perspektiven und Implikationen für die Praxis. Wiesbaden: Springer- Gabler Publishing House, pp.57-76.

Průcha, V. et al. (2004). Socio-economic history of Czechoslovakia 1st Part of period 19181945). (In Czech) Brono: Doplněk..

2. PwC Slovakia homepage (2019). https://www.pwc.com/sk/sk/o-nas.html (Downloaded: 15 July 2019)

Schein, E.H. (2002). Consulting: What Should it Mean? In: Clark, T.R. Fincham: Critical Consulting. Oxford: Blackwell Business.

Schein, E.H. (2016). Humble consulting. Oakland: Berrett-Koehler Publishers, Inc.

Seilerová, M. (2019). The Consequences of Psychosocial Risks in the Workplace in Legal Context. Central European Journal of Labour Law and Personnel Management, 2 (1), 4760.

http://doi.org/10.33382/cejllpm.2019.02.04 
Šimončič, I. S. (1988). Effective management and consulting. (In Slovak) Bratislava: Práca.

Taylor, F. W. (1931). Taylor messages. Praha: Orbis.

Trend (2018). TrendTop 2018. November.

Wireman, T. (2014). Benchmarking Best Practices for Maintenance, Reliability and Asset Management. New York: Industrial Press, Inc.

Žulová, J., Švec, M., Madleňák, A. (2018).

Personality aspects of the employee and their exploration from the GDPR perspective. Central European Journal of Labour Law and Personnel Management, 1 (1), pp. 68 - 77.

http://doi.org/10.33382/cejllpm.2018.01.05

\section{ABOUT THE AUTHORS}

József Poór e-mail: poorj@ujs.sk

Dr. Zsuzsa Szeiner is currently a Ph.D. candidate and assistant lecturer at J. Selye University in Slovakia. She has participated in scientific research projects since 2012. She authored or co-authored numerous publications in Slovak, Hungarian and English languages. Prior to her academic career, she spent 15 years in the private sector as a financial controller.

Dr. Ladislav Mura is an Associate Professor at J. Selye University Komárno, Slovakia. He is working as an Associate Professor at the Faculty of Economics and Informatics of the J. Selye University in Komárno. Assoc. prof. Mura is a Slovak economist and expert on small and medium enterprises, family businesses, international entrepreneurship, and human resource management. $\mathrm{He}$ is an author of 3 domestic scientific monographs, author of 2 foreign scientific monographs, over 40 articles in scientific journals (with impact factor too), including international journals and 30 contributions to conferences.

Dr. Zsolt Horbulák is an assistant professor of the Faculty of National Economy at the University of Economics in Bratislava, Slovakia. Dr. Horbulák was employed in both the private and scientific sphere. During the last ten years, he has worked in four colleges and universities. His primary research areas are the evaluation of the economic and social situation of Southern Slovakia - mainly inhabited by Hungarian minority and Central European economic history. He was a member of several research teams. He is the sole author of four books and co-author of another four, as well as published a great number of proceedings.

Dr. Mike Roberson is a Professor at Eastern Kentucky University, USA. Over his 40-year career as a professor, Dr. Roberson has earned numerous teaching awards and has taught classes in areas such as management, leadership, and advanced H.R. topics such as employee selection and performance management. Since 2001, he has visited China, France, Germany, Hungary, Romania, and Austria, teaching university classes and delivering presentations to business groups and academic conferences. Dr. Roberson's scholarly publications have appeared in a variety of business journals and the Journal of Applied Psychology.

Dr. József Poór is a Professor at J. Selye University Komárno, Slovakia, where he teaches a variety of management courses. He served as a guest professor at five different U.S. universities and taught fourteen short summer semesters. He was as visiting professor at seventeen universities in Europe, where he taught different management subjects. He was a senior manager at internationally recognized professional service firms (Mercer, HayGroup, Diebold). His scholarly publications have appeared in more than thirty-three internationally referred journals. He wrote many books in Hungarian, and seven bookchapters in English and one book in Romanian alone or as a co-author. 